\title{
„KORMÁNYZÁS A FENNTARTHATÓSÁGÉRT"1 (EGY NEMZETKÖZI KUTATÁSI PROGRAM MARGÓJÁRA)
}

\author{
(Governing for Sustainability)
}

\section{VARJÚ VIKTOR}

Kulcsszavak:

Stratégiai környezeti vizsgálat tudástípus környezetpolitika döntéshozás

A környezettudatos gondolkodás kiterjedésével, valamint a fenntartható fejlödés fogalmának széleskörü elfogadásával a gazdasági-, tervezési-, és beruházási beavatkozások környezeti-, környezetvédelmi szempontú hatásainak elözetes értékelése és annak szükségessége egyre fontosabbá és hangsúlyosabbá vált. Az EU által elfogadott stratégiai környezeti vizsgálat (SKV) a tervek és programok szintjén követeli meg az ex-ante jellegü környezeti értékelést.

A tanulmány egy olyan nemzetközi kutatás kérdésfeltevéseit ismerteti, amely a környezetpolitika egyes eszközein (SKV, emisszió-kereskedelem) keresztül elemzi a kormányzás és tudás összefüggéseit.

\section{Bevezetés}

Az Európai Unióval kapcsolatos (társadalomtudományi) politikatudományi kutatások leggyakoribb témája az ún. európaizáció, mely folyamat során az unió szabályozó, orientáló szerepének hatására a tagállamok gazdasági, társadalmi, jogi, politikai és közjogi rendszere közeledik egymáshoz. Az európaizáció sajátossága, hogy nem csupán azokon a területeken ko̊vetkezik be, ahol az alkalmazkodás lényegében kötelező, hanem azon területeken is, ahol nincs ilyen kényszer (Pálné 2005, 11). Éppen ezért nem véletlen, hogy az elmúlt tíz évben az Európai Unióban az integráció mélyülésével egyre eröteljesebben és egyre inkább egységesen érvényesül a környezetpolitika, valamint annak különböző szintủ nemzetközi kutatási igénye is.

Az ezredfordulót követően a magyar környezetvédelmi szabályozásra a jogharmonizációs feladatok tömege volt jellemző, mely azt eredményezte, hogy mára csak elvétve találni olyan közösségi jogszabályt, amelynek nincs magyar megfelelöje, és ez is jellemzóen csak átmeneti állapot (Horváth et al. 2004).

A különböző érvényességủ, szintü, a környezet védelmét szolgáló intézkedések, normák, értékelések (környezeti hatásvizsgálat, környezeti felülvizsgálat, stratégiai környezeti vizsgálat, EMAS rendszer, ISO 14001, EU Hatodik Környezetvédelmi Akcióprogram, II. Nemzeti Környezetvédelmi Program stb.) mind a természeti-, épített-, valamint társadalmi környezetünket hivatottak megvédeni saját tevékenységünk következményeitől. Egyre inkább tudatosítani kell azonban, hogy nem elég szabályozni, hanem szükség van a kormányzás problémáira is felhívni a figyelmet a környezetpolitikában. 
Varjú Viktor : „Kormányzás a fenntarthatóságért" (Egy nemzetközi kutatási program margójára.)

Tér és Társadalom 20. évf. 2006/4. 161-167. p.

A környezeti „felügyeleti” rendszerek közül az egyik új módszer és rendszer a Stratégiai Környezeti Vizsgálat (SKV) melynek magyarországi alkalmazása, valamint tudományos kutatása az elmúlt néhány évben indult meg. E rövid tanulmányban megpróbáljuk bemutatni, hogy milyen lehetöségek rejlenek az SKV-ban, illetve annak kutatásában.

\section{$A z S K V$}

A leíró jellegủ értékelésen túlmutató, az egyre határozottabban megfogalmazódó környezeti hatások és környezeti szempontok figyelembevételének igénye is egyre inkább arra sarkalta a politikusokat, hogy az eddigi hatásértékelések módszereiböl és tapasztalataiból egy önálló komplex vizsgálati rendszert hozzanak létre. Az 1980-as évektől múködő környezeti hatásértékeléssel szemben - mely az effektív beruházások hatásait hivatott vizsgálni - az új metódus már a tervezés szintjén feltételezi a fenntarthatósági értékelést és hatásbecslést.

A COM/96/0511-es tanácsi irányelv egyes részeit, valamint korábbi tapasztalatokat figyelembe véve 2001. június 27-én határozta meg és hozta létre az Európai Parlament és a Tanács a Stratégiai Környezeti Vizsgálatot, mint önálló politikát (környezetpolitikai eszközt) ${ }^{2}$.

$\mathrm{Az}$ irányelv, illetve a stratégiai környezeti vizsgálat célja, hogy védelmet biztosítson az embert körülvevö környezetnek, és hozzájáruljon a környezetvédelmi megfontolások tervekbe és programokba való integrálódásához azok készítési folyamatában, szem elött tartva a fenntartható fejlődés elvét (Pálvölgyi 2006). Ezért környezeti vizsgálatot kell végezni minden olyan terv és program készítésekor, amely valószínüleg jelentős hatással lesz a környezetre (Ferencsik 2004), így vizsgálatot kell végezni a nemzeti, regionális vagy helyi szintú programokhoz kapcsolódva is (pl. ROP, NFT, városfejlesztési koncepciók).

Magyarországon a 2004-ben a Környezetvédelmi Törvény (1995. évi LIII. Tv.) módositása, valamint a 2005. év elején született (2/2005) Kormány rendelet határozza meg a környezeti vizsgálat kereteit az Európai Unió direktívája (2001/42/EK) alapján.

Az SKV-ban jellemzően nem elsősorban egyfajta hatásbecslésről van tehát szó, hanem a környezeti és fenntarthatósági szempontok a programozás korai szakaszában történö érvényesítéséröl, illetőleg a projektek kumulatív környezeti hatásvizsgálatáról (Péti 2005).

A szükebb értelemben vett stratégiai környezeti vizsgálatot Magyarországon megelözte egy, a környezeti érdekeket figyelembe vevö analízis, mely az egyre nagyobb levegöszennyezővé váló közlekedési rendszerek tervezéséhez kötödött. Már 2001ben tehát egy, a hagyományos környezeti hatásvizsgálat és a környezeti stratégiai vizsgálat mezsgyéjén mozgó programértékelési folyamat indult el. Ennek nyomán készült el a Széchenyi-terv autópálya-fejlesztési programjának környezeti szempontú értékelése (melynek két fö célja egyrészt, hogy ésszerüsítse a közlekedési, szállítási igényeket, másrészt, hogy minimalizálja a nem kívánatos környezeti hatásokat [Fleischer et al. 2002]). Ahogy az értékelésben a szerzők jelzik, a Széchenyi-terv 
Varjú Viktor : „Kormányzás a fenntarthatóságért" (Egy nemzetközi kutatási program margójára.)

Tér és Társadalom 20. évf. 2006/4. 161-167. p.

TÉT XX. évf. 2006 - 4

Gyors ténykép

163

autópálya-fejlesztési terveit stratégiai környezeti hatásvizsgálati eljárásnak vetették alá, tehát tudatosan törekedtek meghaladni a korábban alkalmazott módszereket, noha még nem volt kötelezỏ az SKV készítése.

Ugyancsak megelözve a magyar jogszabályi keretek kialakítását - és követve a Széchenyi-terv autópálya-fejlesztési terveinek stratégiai környezeti hatásvizsgálati eljárását - a Regionális Operatív Program környezeti értékelését végzök már 2003ban elkészítették a ROP SKV-ját. Mivel azonban a tervek, programok környezeti hatásainak elözetes értékelésére nem volt általánosan elfogadott módszertan, mindössze az Európai Bizottság által javasolt módszertani anyagok ${ }^{3}$, ezért a ROP-hoz a már említett szakértők által kidolgozásra került egy módszertani keret.

Annak ellenére, hogy Magyarországon tehát voltak már előzményei a stratégiai környezeti vizsgálatnak, az elmúlt években zajló tervezési folyamat nem mentes az ellentmondásoktól. Az Új Magyarország Fejlesztési Terv, a hozzá kapcsolódó ágazati és regionális operatív programok stratégiai környezeti vizsgálata elkészültt. Ahogy a társadalmi vitákból látszott, a vizsgálat módszertana kevésbé, viszont maga a folyamat és annak elhúzódása meglehetősen ellentmondásos megítélésű (lásd: https://www.smartportal.hu/respect/index.php). Az eddigi tapasztalatok arra mutatnak rá, hogy a környezeti szempontok érvényesítése a tervezési folyamatban nem pusztán a jogi szabályozáson, a tervezési módszertanon, hanem a döntési mechanizmuson, a szereplőkön és a szereplök tudásán is múlik.

\section{Az SKV tudás terjedése}

Mivel eddig - a 2007-2013 időszakra vonatkozó, már említett tervekhez kapcsolódó vizsgálatokon kívül - nem készült túl sok SKV, így az eddig felhalmozott tapasztalatokra, és kutatásokra különösen nagy szükség van. Az eddig készített környezeti értékelések jellemzően makro-regionális programokhoz, tervekhez készülttek (2003-as ROP, Széchenyi Autópálya-fejlesztési Koncepció, Országos Fejlesztéspolitikai Koncepció, Magyar Közlekedéspolitikai Koncepció 2003-2015, Vásárhelyi Terv stb.). Mikro-regionális szinten elvétve készült csak néhány értékelés (pl. Óbudai (Hajógyári-) sziget Kerületi Szabályozási Tervének környezeti értékelése $^{4}$ ). A megyei/regionális rendezési tervek és városfejlesztési koncepciók újragondolásakor is környezeti értékelést végeznek majd, illetve a jövőben a területi tervezésben általánosan alkalmazni kell ezt a módszert, ezért a korábbi hasonló vizsgálatok folyamatainak elemzése sok segítséget nyújthat az értékelések sikeresebb végrehajtásához, illetve a környezeti szempontok tervekbe illesztéséhez.

Európa több országában már az 1990-es években vagy jogszabályba foglalták vagy önként alkalmazták a stratégiai környezeti vizsgálatot a tervek szintjén, de nem alakult ki egységes módszertan ezekben az államokban. Ma még mindig a stratégiai környezeti vizsgálatok több változatát különböztetik meg, ezek hatókörben, nyitottságban, intenzitásban és időtartamban is eltérnek egymástól (Szilvácsku 2003).

A programok és tervek környezeti szempontú vizsgálatát nem csak az unióban végezik, hiszen a 2003. május 21-én Kievben elfogadott úgynevezett SKV Protokoll-t 
Varjú Viktor : „Kormányzás a fenntarthatóságért" (Egy nemzetközi kutatási program margójára.)

Tér és Társadalom 20. évf. 2006/4. 161-167. p.

164 Gyors ténykép

TÉT XX. évf. 2006 - 4

- mely részben eltér az Uniós SKV-tól - unión kívüli államok is aláírták (Stoeglehner-Wegerer 2006). Úgy tünik tehát, hogy egy olyan környezetpolitikai eszközröl van szó, amely széles körben elfogadott és alkalmazott eleme lesz a tervezésnek. Kérdés, hogy rendelkezünk-e elegendő tudással, tapasztalattal ennek a módszernek az alkalmazásához?

A tervekhez tartozó környezeti vizsgálat módszertana véleményünk szerint mára már körvonalazódott. A különböző szintủ programokhoz és tervekhez eltérő, de a fenntarthatóságot figyelembe vevö anyagok készülnek.

Az unió célja, hogy valamilyen szinten egységesítse a környezeti értékelést a tagországokban. Ennek érdekében az Interreg IIIC program által finanszírozott GDRP (Greening Regional Development Programmes Network) projekt széles európai részvétellel 2006 februárjában egy kézikönyvet ${ }^{5}$ adott ki. Ez a tanulmány, többek között a magyar 2003-as Regionális Operatív Programhoz létrehozott stratégiai környezeti vizsgálat felhasználásával próbál meg gyakorlati tanácsokat és eszközöket adni, összegezve a résztvevők eddigi tapasztalatait a környezeti elemek regionális fejlesztési programokba történö integrációja kapcsán. Ám ez a kézikönyv sem ad egységes módszertant vagy iránymutatást a stratégiai környezeti vizsgálatok elvégzéséhez, mindössze egy keretet fogalmaz meg, mely könnyebbé teszi a szakértőknek a vizsgálat lefolytatását, illetve emellett a különböző résztvevő országok néhány alkalmazott lépését mutatja be.

\section{Tudás, kormányzás, környezetpolitika}

A környezetpolitikában azonban véleményünk szerint szükséges, de nem elégséges feltétel a szabályozás és a jogszabályi keretek megléte. A hatékony környezetpolitikához megfelelő szisztémájú és megfelelö tudáshalmazzal rendelkezó érdekegyeztető, döntési mechanizmus szükséges. Erről az oldalról érinti a környezeti vizsgálat kutatását a G-FORS ${ }^{6}$ (Governance for Sustainability) EU 6. Keretprogram, amelyben intézetünk is részt vesz. Az SKV itt, mint a környezetpolitika egy eszköze jelenik meg, és mint a vizsgálat tárgya vagy inkább terepe segíti a hatékony kormányzás jellemzőinek feltárását.

A projekt tudásszociológiai megközelítése nem elsősorban az egyes politikák eredményeire, illetve a környezetértékelési módszerek szakmai sajátosságaira koncentrál. A nemzetközi kutatás a kormányzás és a tudás összesített hatását vizsgálja a fenntarthatóság tekintetében. A szociológiai megközelítés mellett azonban kiemelkedő fontossága van a politika tudományi szempontoknak is, azt feltételezve, hogy az egyes szereplők kormányzási pozíciója, és tudáskészlete jelentősen befolyásolja a környezeti szempontok beépülését a döntésekbe. A program különböző környezetpolitikai eszközökön - többek között az SKV-n - keresztül törekszik nemzetközi összehasonlítást is lehetôvé tevő evidenciákat összegyüjteni arról, hogy a tervezésdöntéshozás-végrehajtás folyamatában milyen esélyekkel jelenik meg a fenntartható fejlödés értékrendszere. Az kiindulási alap az, hogy a különbözö kormányzati módok, a konkrét intézményesítési folyamat, valamint maga a szabályozás hogyan 
Varjú Viktor : „Kormányzás a fenntarthatóságért" (Egy nemzetközi kutatási program margójára.)

Tér és Társadalom 20. évf. 2006/4. 161-167. p.

TÉT XX. évf. 2006 - 4

Gyors ténykép

165

hatnak a hatékonyságra és a politikai legitimációra a fenntarthatóságot, mint fö célpontot szem előtt tartva, és ehhez a tudás milyen típusait használják és hozzák létre a folyamat során (Heinelt et al. 2006 a).

A kutatás elsősorban azt próbálja kimutatni, hogy az egyes környezeti politikák hogyan ösztönzik a különböző tudástípusok használatát (szakértői tudás, helyi tudás, gazdasági tudás, vezetői tudás stb.), valamint a kormányzás azon sajátos formáit (hierarchikus, nem-hierarchikus kormányzás stb.), melyek különösen hozzájárulnak a fenntarthatósághoz. A kutatás célja a környezet-politikai játszmák tereinek azonosítását és kapcsolatainak feltárását követően az, hogy elemezze, vajon milyen „tudáskép” („KnowledgeScape”tudástípusok tipikus összetétele) szükségeltetik az egyes környezetpolitikák fenntarthatósági irányba történö elmozdulása érdekében (Heinelt et al. 2006 a).

A kutatás elsősorban retrospektív módon kívánja megvizsgálni a környezetpolitikai küzdötereket, de emellett ahol és amennyiben lehetséges, a résztvevő megfigyelés is helyet kell, hogy kapjon a vizsgálati folyamatban. A ,játszmaterekben" zajló diskurzusokról készült dokumentumok, a környezetpolitikai cselekvésekhez kapcsolódó sajtóanyagok, dokumentumok, jogszabályok és joganyagok képezik a dokumentumelemzés, valamint a diskurzus analízis anyagát. Ezeket az elemzéseket a legfontosabb szereplőkkel készített interjúk és kérdőívek egészítik ki (Heinelt et al. 2006b).

A kutatási koncepció egyik legfontosabb sajátossága, hogy a nemzeti kutatócsoportok a makroszintü jellemzők bemutatását követően zömmel mezo/vagy mikroregionális szinten végzik el a vizsgálatot. Ennek oka nem csak az, hogy a helyi szint ad lehetőséget a leginkább a különböző tudástípusok érvényesülésének az elemzésére, hanem az is, hogy a kutatás koncepciója szerint tipikusan többszintü kormányzási modell érvényesülésére van szükség, ahol az uniós szabályozástól a helyi döntéshozókig több szint és szektor vesz részt a döntési, tervezési folyamatban. Az elemzés magyarországi lefolytatása különösen azért ígérkezik izgalmas és nehéz feladatnak, mert ahogy korábban említésre került, Magyarországon éppen a regionális szinten elvégzett SKV tapasıtalatai jórészt hiányoznak, illetve kezdetlegesek, miközben éppen itt lehet relevanciája az aktív társadalmi részvételnek, nem csak a programozás, hanem a környezeti értékelés tekintetében is.

A kutatási koncepció másik fontos sajátossága és várhatóan értékes eredménye, hogy az SKV-hoz kapcsolódó esettanulmányok tíz nemzet eseteit dolgozzák fel, alkalmat adva a kormányzási rendszerben, a politikai és szakmai kultúrában meglévő különbségek és azonosságok kimutatására. A különbségek nem feltétlenül a posztkommunista és fejlett nyugati államok kormányzási és környezetpolitikai érettségének tekintetében jelentkezhetnek, hanem a regionális sajátosságok, vagy éppen a civil társadalmi megszervezettség különbözöségében is. A kutatási folyamat utolsó, összehasonlító szakaszában lesz lehetőség a megfelelő tudástípusok és kormányzási elemek optimális együttesének meghatározására, nem csak az EU, hanem a nemzeti kormányok környezetpolitikája számára is. 


\section{Összegzés}

A 21. század elején a környezetpolitikának és a hozzá kapcsolódó környezetértékelési rendszereknek nyilvánvalóan helye van a társadalomtudományokban (politika-, földrajz, környezet-, regionális tudomány, szociológia stb.). A fenntarthatóság eszméje megköveteli a holisztikus megközelítést. Éppen ezért, az olyan komplex kutatások eredményei, mint a fentebb felvázolt G-FORS kutatási program, nélkülözhetetlenek nem csak a döntéshozási folyamatban, de a fenntarthatósági cselekvések fenntartható kivitelezésében is.

A kutatásnak olyan, nem tervezett hatása is lehet, hogy az eredményekböl kiolvashatóvá válik, mely tudásformák vezetnek eredményre a fenntarthatóság kritériumainak megvalósításában, így esetlegesen az is meghatározható lesz, hogy a cél érdekében milyen oktatási formák vagy milyen oktatási rendszer szükségeltetik. A kutatás eredményei ahhoz is adalékul szolgálhatnak, hogy a kormányzás mely típusai illetve mechanizmusai (hierarchikus, hálózati, piaci) képesek a leginkább a környezeti szempontok integrálására, s hogy az egyes irányítási szinteken milyen kompetenciák és tudások szükségesek a fenntartható kormányzás megvalósulása érdekében.

A nemzetközi kutatásban való részvétel esélyt ad arra, hogy összevessük, hol tart Magyarország, a magyar kormányzati, irányítási rendszer a környezeti szempontok érvényesítése terén. Nem csak a környezetpolitika formálása, hanem a kormányzás egészének fejlesztése kaphat segítséget azzal, hogy újabb impulzusokat kaphatunk kormányzati rendszerünk decentralizálására, a partneri, részvételi elemek erősítésére.

\section{Jegyzetek}

${ }^{1}$ Governance for Sustainability (G-FORS) nemzetközi projekt - EU 6. Keretprogram 7. prioritás. A magyar partner kutatásvezetöje Prof. Pálné Dr. Kovács Ilona DSc, MTA RKK DTI igazgatója.

${ }^{2} 2001 / 42 / E K$ irányelve az „egyes tervek és programok környezetre gyakorolt hatásainak vizsgálatáról”

${ }^{3}$ Ilyen például a MEANS collection, 1999.

${ }^{4}$ http://www.obuda.hu

${ }^{5}$ Handbook on SEA for Cohesion Policy, 2006.

${ }^{6}$ EU Commission's Research Framework Programme 6, 7. prioritása (Állampolgárok és kormányzás a tudásalapú társadalomban) a Metropolregion of Hannover, EUROCITIES vezetésével és tíz egyetem, valamint kutatóközpont közremúködésével: University of the West of England-Bristol, Darmstadt University of Technology, University of Warsaw, University of Twente, Politecnico di Milano, University of Göteborg, Norwegian Institute for Urban and Regional Research, Panteion University, MTA RKK, és IRS-Erkner (Németország). www.gfors.eu.

\section{Irodalom}

Czira T.-Jusztin V.-Sóvágó K. (2004) A társadalmi-gazdasági és környezeti hatásértékelés szerepe a terủleti tervezésben. - Területi statisztika. 1. 3-20. o.

Evaluating socio-economic progranmes (MEANS Collection). (1999) European Commission, Luxembourg. 1-6. o.

Fleischer (et al.) (2002) A Széchenyi-terv autópálya-fejlesztési programjanak stratégiai környezeti vizsgálatáról. MTA VKI Múhelytanulmányok. 40. Budapest. http://www.vki.hu/muhelytanulmany.shtml\# [cit. 2006.08.28.]. 
Varjú Viktor : „Kormányzás a fenntarthatóságért” (Egy nemzetközi kutatási program margójára.)

Tér és Társadalom 20. évf. 2006/4. 161-167. p.

Fleischer T. (et al.) (2004) Gondolatok a közlekedés-fejlesztési programok stratégiai környezeti vizsgálàtáról. - ÖKO. 1-2. 56-66. o.

Fleischer T. (et al.) (2005) A magyar közlekedéspolitika stratégiai környezeti vizsgálata. - Közlekedéstudományi Szemle. 2. 47-54. o.

Ferencsik 1. (2004) Stratégiai Környezeti Vizsgálat (SKV) - az alapok. - Falu, Város, Régió. 6. 51-55. o.

Handbook on SEA for Cohesion Policy 2007-2013. (2006) GRDPN. http://www.epa.ie/ TechnicalGuidanceandAdvice/GuidanceDocuments/pdfsforguidancedocuments/FileUpload,9149,en.pdf [cit. 2006.08.28.]

Horváth Zs.(et al.) (2004) Az Európai Unió környezetvédelmi szabályozása. KJK-Kerszöv Kft., Budapest.

Heinelt, H. (et al.) (2006a) Governance for Sustainability. (Conceptual Frame) G-FORS Project, Darmstadt/Erkner.http://www.g-fors.eu/fileadmin/download/papers/GFORS_ConceptualFrame_Bristol.pdf [cit. 2006.12.21.].

Heinelt, H. (et al.) (2006 b) Methodological Framework. hittp:/www.g-fors.eu/fileadmin/download/papers/ MethodologicalFramework.pdf [cit. 2006.12.21.].

Pálné K.I. (2005) Kơzigazgatási reformok, uniós tagság, regionalizmus. - Pálné K.I. (szerk.) Regionális reformok Európában. Timp Kft., Budapest, 9-42. o.

Pálvölgyi T. (2006) A stratégiai környezeti vizsgálatok klíma elemei. - „Agro-2I" Füzetek. 47, 3-15. o.

Péti M. (2005) A stratégiai környezeti vizsgálat a fenntartható (terủleti) tervezés szolgálatában. - Falu, Város, Régió. 3-4. 43-56. o.

Stoeglehner, G.-Wegerer, G. (2006) The SEA-Directive and the SEA-Protocol adopted to spatial planning - similarities and differences. - Environmental Impact Assessment Review. 26. 586-599. 0. http://www.sciencedirect.com [cit. 2006.10.01.].

Szilvácsku Zs. (2003) Stratégiai környezeti vizsgálatok gyakorlata az Európai Unióban. Vitaregnat Bt., Budapest.

Tombácz E. (et al.) (SKV csoport) (2003) Stratégiai Környezeti Vizsgálat. Egy lehetséges módszertan a Regionális Operativ Program kömyezeti szempontú ex-ante értékelésének megalapozásához. http://www.rec.hu/skv [cit. 2006.06.29.].

http://www.gfors.eu.

http://www.obuda.hu.

https://www.smartportal.hu/respect/index.php. 